\title{
Cesta do Ruska
}

\section{A Journey into Russia}

\section{Jan Zouhar}

Koncem května a v první polovině června roku 1867 se reprezentativní skupina českých veřejných činitelů (F. Palacký, F. L. Rieger, F. A. Brauner, Július Grégr ad.) vypravila do Moskvy na národopisnou výstavu a do Petrohradu, kde byli 26. 5. 1867 přijati carem Alexandrem II. Politický význam akce celé byl problematický, ruský vyslanec ve Vídni informoval rakouské úřady, že carské Rusko nemá zájem ovlivňovat řešení vnitřních rakouských problémů. Součástí cesty našich politických představitelů byla účast na slovanském sjezdu, kterého se zúčastnily reprezentace všech slovanských národů tehdejší Evropy. Přes kritické výhrady některých našich osobností vzbudila tehdejší cesta do Ruska nadšení a nárůst proruských a proslovanských sympatií.

Výročí tohoto slovanského sjezdu se stalo podnětem k mezinárodní konferenci, kterou pořádala univerzita v Sankt-Petěrburgu. A tak se ve dnech 22. 9. - 2. 10. 2017 na pozvání Institutu filozofie univerzity v Sankt-Petěrburgu vypravila reprezentantivní dvojice brněnských filozofư H. Pavlincová a J. Zouhar do Ruské federace.

První část svého pobytu v Moskvě věnovali studiu zastoupení české filozofické literatury v Rossijskoj gosudarstvennoj bibliotěke a v Bibliotěke istorii russkoj filosofii i kultury. V Moskvě si prohlédli i Kreml a jeho chrámy a muzea a také Novoděvičí hřbitov, kde jsou pochováni významní představitelé ruské kultury a politiky. Navštívili také Sergijev Posad (Zagorsk), významné středisko ruské pravoslavné církve.

K druhé části pobytu v Petrohradě přejeli z Moskvy vlakem Sapsan. Tento vysokorychlostní vlak, jehož soupravy vyrobila firma Siemens, jezdí z Moskvy do Sankt-Petěrburgu a zpět třináctkrát denně, jízda trvá od 3 hodin 46 minut do 4 hodin 10 minut podle počtu zastávek (některé spoje mají pouze jednu zastávku, některé zastavují pětkrát). 
V Sankt Petěrburgu se pak ve dnech 27. - 29. 9. 2017 konala za účasti 96 vysokoškolských a akademických pracovníků z Ruska, Ukrajiny, Běloruska, Polska, Česka, Slovenska, Srbska, Bulharska, Lotyšska a Japonska mezinárodní vědecká konference Slavjanskaja iděja v istorii i sovremennosti. K 150-letiju slavjanskogo sjezda.

Oba brněnští reprezentant se jí aktivně zúčastnili a přednesli své př́ispěvky. H. Pavlincová hovořila na téma Iděja slavjanofilskogo filosofskogo kongressa v dvacatych godach XX veka na plenárním zasedání, které se konalo v historických prostorách Aktovovo zala Sankt-Petěrburskogo universitěta v Zdaniji dvenadcati kolegij, J. Zouhar vystoupil s příspěvkem T. G. Masarik $i$ slavjanstvo (K masarikovskomu analizu dualizma zapadničestva i slavjanofilstva v russkom soznanii) v sekci Slavjanofilstvo: istorija, iděologija, filosofija, (Další dvě sekce se konaly pod názvy Filosofija u slavjan: koncepcii, portréty, perspektivy a Russkaja filosofija v otěčestvennych i zarubežnych issledovanijach.) Helena Pavlincová ve svém referátu Idea slovanského filosofického kongresu ve dvacátých letech 20. století přiblížila tři pokusy o svolání slovanského filozofického kongresu: Prvý inicioval záhřebský filozof Vladimir Dvorniković článkem, který vyšel v květnu 1923 v deníku Prager Presse. Apeloval v něm na Slovany, aby získání své státní a národní samostatnosti doplnili duchovní emancipací prostřednictvím filozofie jako syntetizujícího činitele a usilovali o vzájemné poznání a sblížení. Za nejvhodnější místo pro setkání slovanských filozofů označil Prahu, nebot má centrální pozici mezi severními a jižními Slovany, organizovaný filozofický život a žije v ní T. G. Masaryk, „nestor slovanských sociologů a filosofů“. Pavlincová zdůvodnila, proč Dvorniković a po něm i další hlasatelé všeslovanských snah přisoudili Masarykovi v tomto úsilí klíčovou roli. Připomněla, že Masaryk, v té době už prezident Československé republiky, svými činy (např. angažovaností v záhřebském procesu) i literárním dílem (zájmem o ruského slavjanofila Ivana V. Kirejevského, o Dostojevského a Tolstého, spisem Rusko a Evropa) proslul už dávno před válkou jako aktivní stoupenec slovanské vzájemnosti a tuto ideu podporoval praktickými činy i v době svého prezidentství, když pomáhal nejen ruským intelektuálům, kteří po Říjnové revoluci v roce 1917 emigrovali do Československa, ale také ruským spisovatelům a umělcům, kteří se uchýlili do dalších zemí. Výzva V. Dvornikoviće na uspořádání slovanského filozofického kongresu byla slovanskými filozofy příznivě přijata, vzácně pospolité byly zprvu i reakce českých filozofů (prokongresový postoj nejhorlivěji zastával Karel Vorovka), ale dosud jednotný názor se začal tříštit a záměr se nepodařilo uskutečnit. 
Druhý pokus o svolání kongresu slovanských filozofů v Praze se udál při př́ležitosti pátého mezinárodního filozofického kongresu v Neapoli (květen 1924). Přítomní slovanští filozofové na společném setkání zvolili dokonce přípravný výbor, jehož členové měli pro myšlenku kongresu získávat ve svých zemích další stoupence. Pozitivistická Česká mysl od záměru ustoupila s odůvodněním, že na svolání sjezdu není nyní vhodná doba, a pokud by se filozofové dohodli, že takový sjezd uskuteční, neměli by Češi přitom hrát vưdčí roli. A pokus třetí - v záŕí 1927 se ve Varšavě konal druhý polský filozofický kongres za velké účasti slovanských hostů, takže tisk poněkud nadneseně psal o všeslovanském sjezdu; nejpočetnější byla delegace ruských (a ukrajinských) emigrantů. Všichni přítomní opětovně projevili velký zájem, aby se slovanský kongres v Praze konal, a pověřili filozofa Karla Vorovku, aby tuto myšlenku pomohl realizovat. Jeho snaha však také tentokrát pro nezájem hlavních reprezentantů pražského filozofického života (F. Krejčího, E. Rádla) vyzněla naprázdno.

I když se tedy ve 20. letech nepodařilo kongres uskutečnit, zájem o filozofii slovanských národů ve světě i v Československu nadále trval. V průběhu 30. let se tematika slovanské filozofie objevovala v časopisech Česká mysl a zejména Ruch filosofický, kde vycházela i monotematická „slovanská“ čísla. Vedle příspěvků ruských a ukrajinských filozofư žijících v té době v Československu značnou pozornost vzbuzovala i filozofie polská, roku 1932 vyšel sborník Současná filosofie u Slovanů, v překladu F. Pelikána a nákladem Slovanského ústavu byly vydány obsáhlé Dějiny ruské filosofie Borise Jakovenka.

Jan Zouhar ve svém referátu Masaryk a slovanstvi pak ukázal, že ruská a slovanská otázka se pro T. G. Masaryka stala jedním z jeho celoživotních témat. Masaryk navštívil Rusko poprvé na jaře v roce 1887 a hned v roce 1888 se tam vydal znovu. Masaryk byl už před svou první cestou do Ruska poměrně podrobně seznámen s ruskými poměry. Třetí cestu do Ruska podnikl v roce 1910, čtvrtou pak v letech 1917-1918. V předvečer 1. světové války svůj př́ístup k Rusku vyjádřil ve spisu Rusko a Evropa (1913), který je vůbec nejobsáhlejším Masarykovým spisem. Vyvrcholil v něm jeho dlouholetý vztah k ruské kultuře, myšlení a dějinám. V Rusku a Evropě prokázal Masaryk zevrubnou znalost ruských kulturních a politických poměrů. Pro svou mimořádnou informační hodnotu text nezastaral a dodnes může sloužit jako základní př́iručka ke studiu ruských intelektuálních dějin. Masaryk se už od sedmdesátých let 19. století snažil najít podstatu ruského myšlení. Masarykova kritika mírí zejména proti dvěma rozhodujícím tendencím ruského duchovního života - krajnímu konzervatismu (teokracii) a krajnímu anarchismu (nihilismu, 
terorismu). Masaryk pokládal slavjanofilství za pokus o obnovu teokracie, za první uvědomělejší slovanskou filozofii náboženství a dějin, za výraz slovanského mesianismu. Vědecká slabost slavjanofilství je podle něho v noetických základech celého systému. Zde Masarykova analýza ruských duchovních poměrů souvisí s úvahami o politických aspektech slovanské problematiky a představuje jednoznačné odmítnutí jak panslavismu, tak slavjanofilského principu svobody od politiky a lidové jednoty bez svobody.

Aktivní účast na konferenci doplnily individuální konzultace se členy katedry historie ruské filozofie a kultury prof. Malinovem a doc. Rybasem, které byly zaměřeny na metodologické problémy dějin národních filozofií.

Přiměřená část pobytu v Petrohradu byla věnována historickým a kulturním pamětihodnostem města a kulturní a společenská část konference vyvrcholila projížd'kou po Něvě na „filosofskom parochodě“.

prof. PhDr. Jan Zouhar, CSc.

Katedra filozofie, Filozofická fakulta, Masarykova univerzita

Arna Nováka 1, 60200 Brno, Česká republika

zouhar@phil.muni.cz 